as quickly or slowly as each student wishes.

Payment: Select one of two plans: 1) Plan 1. \$88.00 in advance. You may purchase the first eight seminars now at $\$ 11.00$ each minus the registration fee. You will receive the ninth seminar free. 2) Plan 2. $\$ 95.00$. You may purchase the first eight seminars one at a time at $\$ 11.00$ each plus a registration fee of $\$ 7.00$. You will receive the ninth seminar free.

If interested in more information or enrolling, write: Seminars in Ornithology, Cornell Laboratory of Ornithology, 159 Sapsucker Woods Road, Ithaca, New York 14850. Cheques should be made payable to the Cornell Laboratory of Ornithology.

\title{
THIRTEENTH
}

\section{ANNUAL NESTBOX REPORT Of the Brandon Junior Birders}

\section{by JACK LANE* and CHRISTOPHER MARTIN**}

Due to the very mild and open winter of $1972-73$, our club set out a record number of nestboxes, over 650 before the year's first bluebirds appeared this spring. Most of the boxes were built and donated by a retired railroader, W. E. Forsyth. Due to his continuing efforts, our weekly winter nest-building bees are now finished. With a present total of over 4,100 nestboxes scattered along more than 1,400 miles of nestline, it is no longer practicable to attempt a check of the nests and, beginning with this report, we will estimate all nestings of bluebirds.

Noteworthy this year is a decrease in the number of nestings of the Eastern Bluebird. Some effort was made to check the nestings of this species but it was not comprehensive, and a combined check and estimate shows a drop of 25 nestings from last year. We believe this may be attributed to the increasing numbers of nestboxes being set out by two groups in the Selkirk-Winnipeg areas. Since our local Eastern Bluebirds pass that way in spring migration, it appears quite likely that more and more of them will stay in eastern Manitoba to raise their families.

One of our new nestlines, running north from Kirkella to north of Russell, has James Spear in charge of it and others around Russell. The highlight of his report is the nesting of a pair of Easterns in the Assiniboine Valley west of Russell. After enlisting the aid of our local biologist, Larry Bidlake, in the fight against the plague that decimated the first-broods of Mountain Bluebirds both in 1970 and 1972, the malady did not appear this year. We are inclined to blame this everyther-year epidemic on blood-sucking Black flies. Bidlake had provided us with a spray to be used in the nestboxes.

This year also yielded our fifth example of a male hybrid. Rather late in the summer he took over a nestbox on the Hooke Ranch, south of Camp Hughes; he was mated to a normal Eastern female that laid four eggs. Since two earlier crosses between a hybrid male and a normal Eastern hen had produced only one paby from a total of 11 eggs, we thought this 1973 pair might have infertile eggs. They confounded us by hatching all four eggs. 
Among the older nestlines, Mountain Bluebirds appear to have reached the saturation point in nestings; notable among these are the SOUTHEAST LINE, run by Ed Robinson, and the SOUTHWEST LINE of Art Giles, as well as the TRANSCANADA LINE.

The common House Sparrow has now assumed the title of chief enemy of the bluebirds. We have previously noted in the Blue Jay for December, 1970, how this pest had taken over the BRANDON-GLADSTONE-AUSTIN LINE. The same calamity overtook the NORTHWEST LINE this year; where a day's banding last year yielded 265 bluebirds on this route, the total for a day this year was 38 banded. Sparrows had taken over about two-thirds of the nests, cornering and killing the adult bluebirds when they got in the way. Little can be done to combat these tough vandals, and the only solution seems to be to move the entire nestline to a new area.

Lack of time this season limited the banding of bluebirds to only 1,684 , but this does bring our four-year total to over 10,000 bluebirds banded. Our estimated nestings this season follow:

$\begin{array}{lrlrlr}\text { Mountain Bluebirds } & 825 & \text { Tree Swallows } & 2450 & \text { Starlings } & 10 \\ \text { Eastern Bluebirds } & 150 & \text { House Sparrows } & 225 & \text { Deer Mice } & 90 \\ \text { Hybrid Bluebird } & 1 & \text { House Wrens } & 35 & \text { Red Squirrels } & 10\end{array}$

\title{
1972 ALBERTA RAPTOR BANDING REPORT
}

\author{
by CHRIS S. REES*
}

1972 proved to be a highly successful year for the group of Albertan raptor banders with a final count of 1,399 birds of 22 species banded. This brings the total raptors banded by the group to approximately 3,840 since 1967 . The banders involved were: Harry Armbruster, Rod Burns, John and Nial Campbell, Tom Donald, Richard, Ken, Kip and Kelly Fyfe, Ron Gallant, Bob Gehlert, Michael J. Hampson, Pat Harris, Keith Hodson, Wolfe Hoffmann, Mike Johnson, Edgar T. Jones, Lynne and Brian Kemper, Brian Nicolai, Chris Rees, Tom Russell, Dave Schowalter, Rich Svrcek, Ken Trann, Phil Treffery and Bruce Treichel.

Early in the winter of 1971-72 several Gyrfalcons were sighted. Snowy Owls were common but difficult to catch in the later part of the winter. These owls are again common this winter (1972-1973) and perhaps a little more responsive to trapping technique. Sparrow Hawks were reasonably numerous on the spring migration but proved to be so difficult to trap that several banders became discouraged and went on to band other species. This resulted in a drastic drop in the number of Sparrow Hawks banded as compared to the 1971 count. Both Long-eared and Short-eared owls were common this summer. Two large concentrations of Short-eared Owls could be noted, one north and one south of the city of Edmonton. Several members of the group worked very hard in the area south of the city finding 18 to 20 nests. Several of the nests found north of the city were destroyed either by farming operations or by predation. Long-eared Owls could be found nesting in nearly every willow and poplar tangle and others were heard hooting from heavier woods earlier in the spring. These large concentrations of eared-owls probably indicate a high population of mice and voles which in turn could explain the poor success in Sparrow Hawk trapping.

The highlight of the fall had to be the tremendous movement of Goshawks into and through the district. The use of the "swede" trap proved to be very effective

*No. 2 - 13027 - 83rd St., Edmonton, Alberta. 